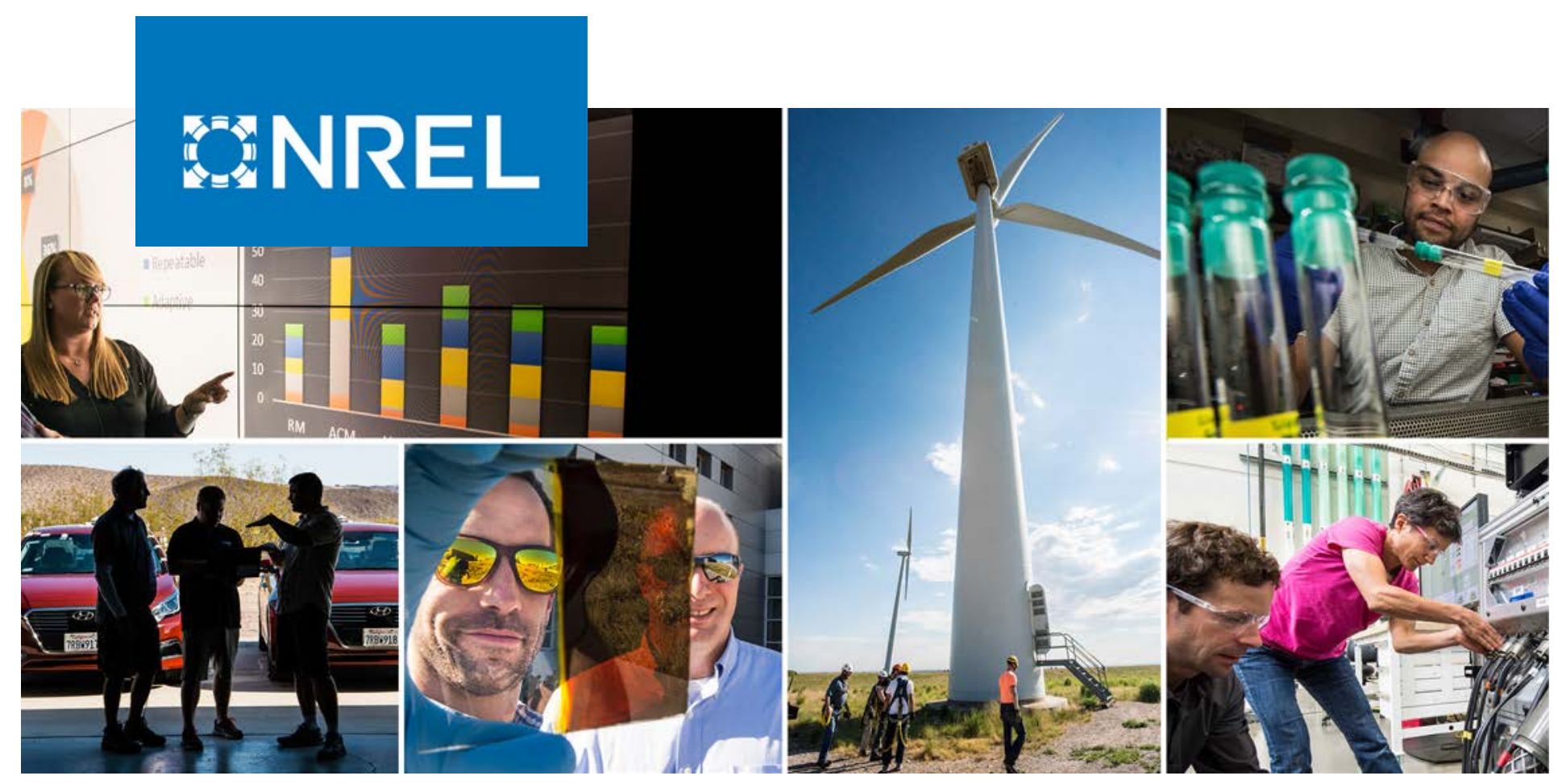

\title{
Business Models to Accelerate the Utilization of Distributed Energy Resources
}

Kaifeng Xu, Yi Min Zhang, Rob Hardison, and Elizabeth Weber

National Renewable Energy Laboratory

NREL is a national laboratory of the U.S. Department of Energy Office of Energy Efficiency \& Renewable Energy

Operated by the Alliance for Sustainable Energy, LLC

This report is available at no cost from the National Renewable Energy Laboratory (NREL) at www.nrel.gov/publications.
Technical Report

NREL/TP-6A20-79549

November 2021 


\title{
GNREL
}

\section{Business Models to Accelerate the Utilization of Distributed Energy Resources}

\author{
Kaifeng Xu, Yi Min Zhang, Rob Hardison, and \\ Elizabeth Weber
}

National Renewable Energy Laboratory

\section{Suggested Citation}

Xu, Kaifeng, Yi Min Zhang, Rob Hardison, and Elizabeth Weber. 2021. Business Models to Accelerate the Utilization of Distributed Energy Resources. Golden, CO: National Renewable Energy Laboratory. NREL/TP-6A20-79549.

https://www.nrel.gov/docs/fy22osti/79549.pdf.

NREL is a national laboratory of the U.S. Department of Energy Office of Energy Efficiency \& Renewable Energy Operated by the Alliance for Sustainable Energy, LLC

This report is available at no cost from the National Renewable Energy Laboratory (NREL) at www.nrel.gov/publications.

Contract No. DE-AC36-08GO28308
Technical Report NREL/TP-6A20-79549 November 2021

National Renewable Energy Laboratory 15013 Denver West Parkway Golden, CO 80401 303-275-3000 • www.nrel.gov 


\section{NOTICE}

This work was authored by the National Renewable Energy Laboratory, operated by Alliance for Sustainable Energy, LLC, for the U.S. Department of Energy (DOE) under Contract No. DE-AC36-08GO28308. Funding provided by The Children's Investment Fund Foundation (CIFF). The views expressed herein do not necessarily represent the views of the DOE or the U.S. Government.

This report is available at no cost from the National Renewable Energy Laboratory (NREL) at www.nrel.gov/publications.

U.S. Department of Energy (DOE) reports produced after 1991 and a growing number of pre-1991 documents are available free via www.OSTI.gov.

Cover Photos by Dennis Schroeder: (clockwise, left to right) NREL 51934, NREL 45897, NREL 42160, NREL 45891, NREL 48097, NREL 46526.

NREL prints on paper that contains recycled content. 


\section{Acknowledgments}

The authors would like to thank the following individuals and organizations for their thoughtful review of this work: David Hurlbut (National Renewable Energy Laboratory [NREL]), Naim Darghouth (Lawrence Berkeley National Laboratory). We also appreciate the insights from Yongqiang Zhao (China National Renewable Energy Centre). Lastly, we would like to express our gratitude to the NREL communications team for all their support in bringing this and many other publications into the public domain. 


\section{List of Acronyms}

DER

DSO

ESP

FERC

$\mathrm{GW}_{\mathrm{DC}}$

IOU

IPP

NEM

PV

RPS

RTO

VPP distributed energy resource

distribution system operator

energy service provider

Federal Energy Regulatory Commission

gigawatts-direct current

investor-owned utility

independent power provider

net energy metering

photovoltaic

renewable portfolio standards

regional transmission operator

virtual power plant 


\section{Table of Contents}

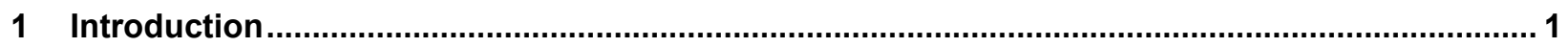

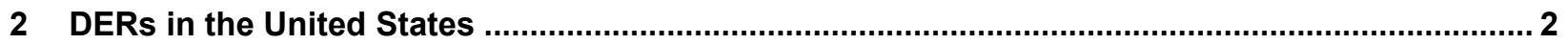

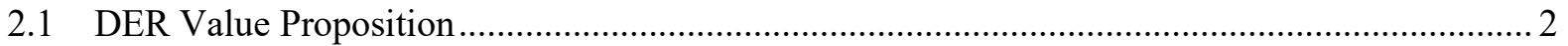

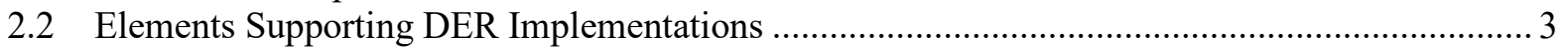

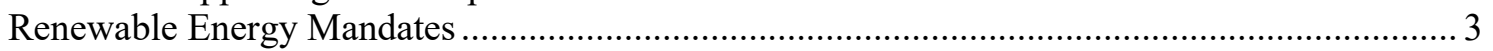

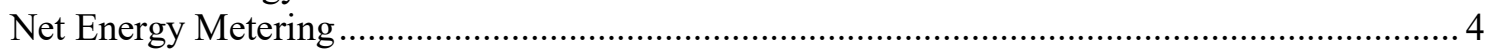

Renewable Energy Auctions .................................................................................. 4

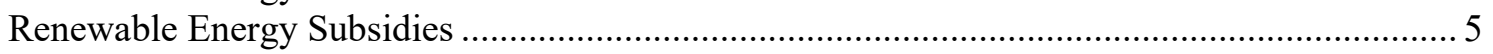

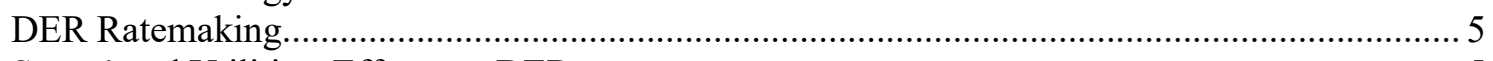

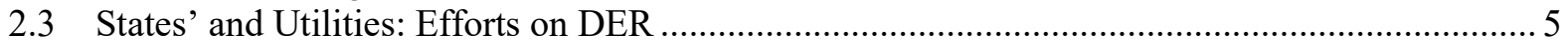

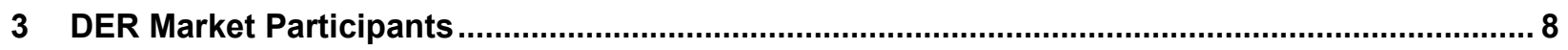

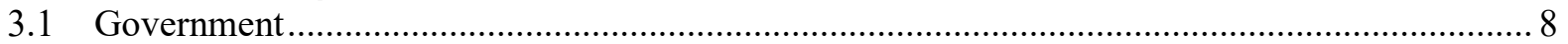

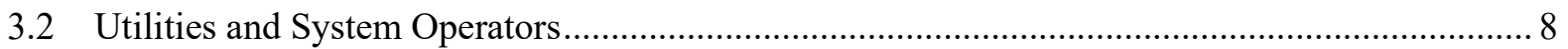

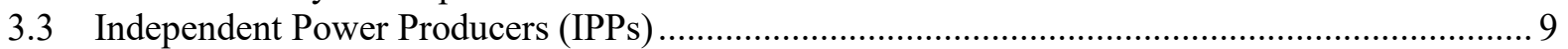

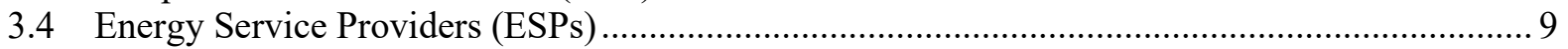

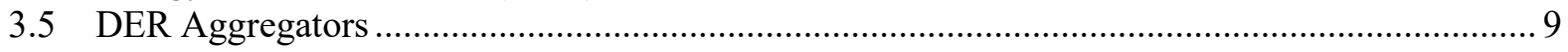

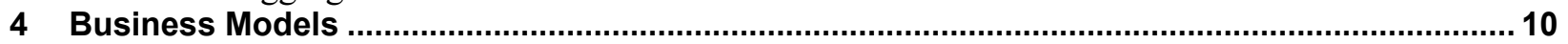

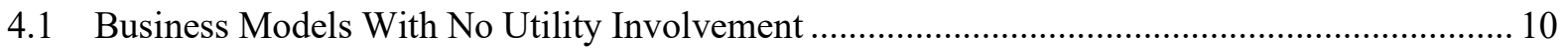

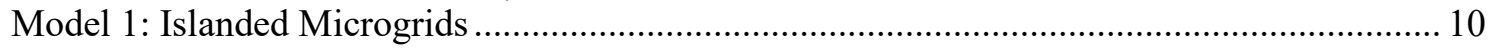

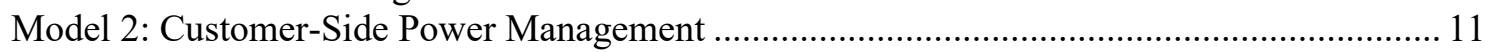

4.2 Business Models Depending on Policy and Utility Applications .......................................... 12

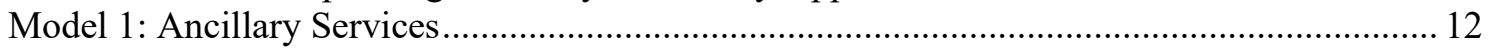

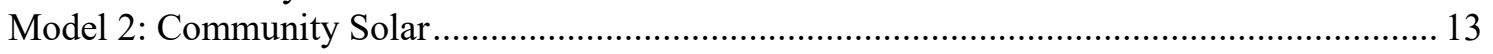

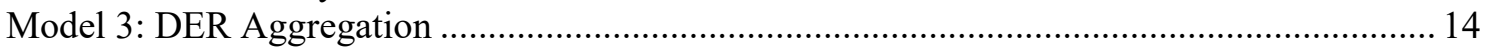

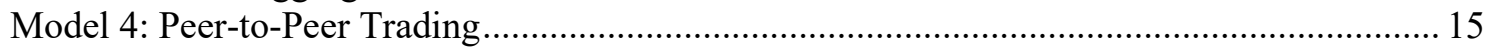

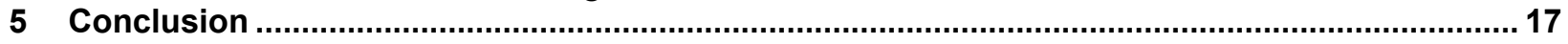

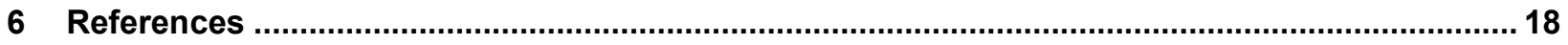




\section{List of Figures}

Figure 1. U.S. states that enable RPS or equivalent mandates.............................................................. 4

\section{List of Tables}

Table 1. DER Value from Avoided Cost Across the Power Delivery Stage ............................................ 2

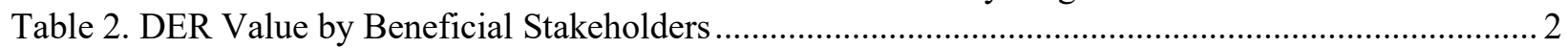

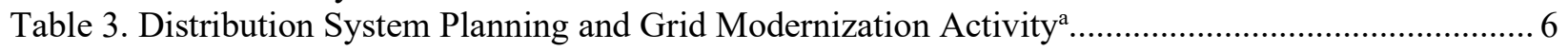

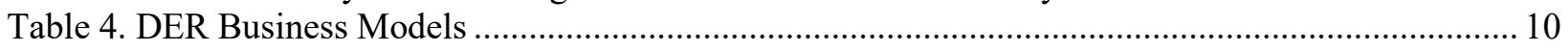

Table 5. Islanded Microgrids Model: Required and Supportive Features, Advantages and Disadvantages

Table 6. Customer-Side Power Management Model: Required and Supportive Features,

Advantages and Disadvantages..................................................................................... 12

Table 7. Ancillary Services Model: Required and Supportive Features, Advantages and Disadvantages . 13

Required Policies/Regulations/Technologies ................................................................................. 13

Table 8. Community Solar Model: Required and Supportive Features, Advantages and Disadvantages .. 14

Table 9. DER Aggregation Model: Required and Supportive Features, Advantages and Disadvantages.. 15

Table 10. Peer-to-Peer Trading Model: Required and Supportive Features, Advantages and Disadvantages 


\section{Introduction}

The U.S. power system is experiencing increasing deployment of distributed energy resources (DERs) in part as a result of advances in technologies and policies at the federal and state levels. Though DER is a commonly used term by the energy industry, no uniform definition for DER exists. DERs typically refer to geographically dispersed and smaller generation resources on the distribution system. With emerging technologies, the definition of DER has evolved to include energy storage, demand response, energy efficiency and others (e.g., electric vehicles), in addition to energy generation resources. Therefore, any non-bulk energy system resource, such as distributed generation (e.g., solar, wind, and biomass), a behind-the-meter application, energy storage facility, DER aggregation, microgrid system, or demand response could be defined as DER. The Federal Energy Regulatory Commission (FERC, 2018) defined a DER as "a source or sink of power that is located on the distribution system, any subsystem thereof, or behind a customer meter."

Over the last decade, solar photovoltaic (PV) and energy storage have contributed the most to the DER deployments in the United States. The total installed solar PV capacity reached 108.7 GW DC in Q2 2021 (SEIA, 2021b). Residential PV and nonresidential PV (e.g., community solar) serve as DERs, which reached 18.6 GW $\mathrm{GC}_{\mathrm{DC}}$ and $3.9 \mathrm{GW}_{\mathrm{DC}}$ as of 2020 (NREL, 2021; Wood Mackenzie, 2021). And 3.3 GW of energy storage had been installed as of 2020, and this figure is expected to reach $43.4 \mathrm{GW}$ in 2026 cumulatively. In addition, cumulative residential storage contributed $14.9 \%$ (488 MW) and 14.5\% (6,159 MW) of cumulative storage deployments as of 2020 and 2026 respectively (Wood Mackenzie, 2021).

With increasing DER deployment, challenges emerge regarding DER integration, system operation, regulation, value stacking, and other DER-related topics. In this report, we provide an overview of the DER value proposition and market participants in the U.S. market, and we identify the potential options for DER business model applications. We review both the existing business model and those at early-stage innovations to illustrate the potential of DER applications. For each business model, we analyze the fundamental and supportive policies and the market status and provide high-level pros and cons. In Section 2, we discuss the value proposition of DERs as well as the key policies and elements to enable the emergence and growth of the DER market in the United States. Section 3 details the DER participants and their roles. Section 4 presents a review of business models for adopting DERs, including both present practices and early-stage options. It is followed by concluding notes in Section 5. 


\section{DERs in the United States}

Deployment of DERs has been increasing in the United States over the last decade. In this section, we discuss the value of DERs, as well as the fundamental policies that create a legal, regulatory, and market framework for DERs. And we illustrate states' efforts on DERs.

\subsection{DER Value Proposition}

DER values keep expanding with increasing deployment and more interaction with the grid system. (Frick et al., 2021) categorized the DER value in generation, transmission, and distribution systems, as shown in Table 1.

Table 1. DER Value from Avoided Cost Across the Power Delivery Stage

\begin{tabular}{|l|l|l|l|}
\hline Value Category & $\begin{array}{l}\text { Generation } \\
\text { (System Values) }\end{array}$ & Transmission & $\begin{array}{l}\text { Distribution } \\
\text { (Locational Values) }\end{array}$ \\
\hline Energy & $\begin{array}{l}\text { Fuel combustion, power } \\
\text { purchase agreement costs }\end{array}$ & Transmission losses & Distribution losses \\
\hline Capacity & $\begin{array}{l}\text { New power plants and } \\
\text { storage resources }\end{array}$ & $\begin{array}{l}\text { New transmission } \\
\text { facilities }\end{array}$ & $\begin{array}{l}\text { New distribution } \\
\text { facilities }\end{array}$ \\
\hline Operation & Ancillary services & $\begin{array}{l}\text { Ancillary services, volt- } \\
\text { var control }\end{array}$ & Voltage and var control \\
\hline Environment & $\begin{array}{l}\text { Air emission, land use, } \\
\text { water, waste }\end{array}$ & $\begin{array}{l}\text { Land and right-of-way } \\
\text { procurement }\end{array}$ & $\begin{array}{l}\text { Land and right-of-way } \\
\text { procurement }\end{array}$ \\
\hline
\end{tabular}

The significant benefits DERs can provide to the grid system have been discussed in many studies. For example, A DERs future study conducted by Lawrence Berkely National Laboratory categorized DER value components in wholesale, distributed, and customer and societal aspects (De Martini and Kristov, 2015). At the wholesale level, DERs reduce the energy capacity required to meet local requirements, reduce the cost for maintaining system balancing and electric grid reliability, mitigate the congestion and losses caused by transmission, and reduce the quantity of energy production. DERs provide similar benefits at the distribution level and create a more flexible and reliable grid system. Regarding customer and societal benefits, DERs provide more customer energy access choices, and they benefit the environment by reducing emissions. (Tierney, 2016) illustrated DER values for various stakeholders as shown in Table 2.

Table 2. DER Value by Beneficial Stakeholders

\begin{tabular}{|l|l|}
\hline DER Value & Description \\
\hline Retail electricity customer & $\begin{array}{l}\text { DERs provide retail electricity customer options to receive bundled or } \\
\text { unbundled electricity services, enable net energy metering, and provide } \\
\text { more-flexible rate structures. }\end{array}$ \\
\hline Electric system & $\begin{array}{l}\text { This category includes DER's value to generation, transmission, } \\
\text { distribution. For generation, DERs help achieve lower cost of aggregate } \\
\text { demand. For transmission, DERs could avoid the cost of high-voltage } \\
\text { transmission. For distribution, DERs could provide reliable distribution } \\
\text { service. }\end{array}$ \\
\hline
\end{tabular}




\begin{tabular}{|l|l|}
\hline DER Value & Description \\
\hline Participating customer & $\begin{array}{l}\text { Customers benefit by receiving electricity from DER systems, net of } \\
\text { costs, such as installation, operation, and system maintenance. These } \\
\text { benefits could help improve resiliency, stabilize energy prices, and } \\
\text { provide flexible services. }\end{array}$ \\
\hline Local community & $\begin{array}{l}\text { These values are considered externalities (e.g., creating new jobs, } \\
\text { reducing emissions, and stimulating the local economy). }\end{array}$ \\
\hline
\end{tabular}

\subsection{Elements Supporting DER Implementations}

Policy and market attributes affect DER deployments. In the United States, both federal and state authorities have developed regulations, schemes, and market incentives for DERs. Though a wide range of elements that support DER development could be considered enabling factors, we focus on five policy and market elements that have promoted the growing adoption of DERs in the United States, including:

- Renewable energy mandates

- Net energy metering

- Renewable energy auctions

- Renewable energy subsidies

- DER ratemaking.

We do not address other attributes such as electrical vehicle to grid, block chain, and other earlystage schemes.

\section{Renewable Energy Mandates}

Renewable energy mandates such as renewable portfolio standards (RPS), clean peak standards, energy storage targets, and other distributed renewable resources-related policies have enabled the emergence of a market for DER deployments. RPS are widely adopted across the United States. As of 2020, 30 states and Washington, D.C. (Figure 1, page 4) have adopted RPS and equivalent policies like clean peak standards (DSIRE, 2020b). In general, RPS set a minimum requirement for the share of electricity generated by specific renewable resources. For example, California Senate Bill 100 mandates that $60 \%$ of electricity is generated by renewable resources by 2030 (California Legislative Information, 2018).

RPS apply to both utility-scale and distributed generation resources, and they have been a critical driver of renewable expansion in the United States. Although RPS policies vary by state, 19 states and the Washington, D.C. have carve-outs or multipliers schemes for solar and distributed generation. According to an RPS compliance analysis by Lawrence Berkeley National Laboratory, in 2019, 23\% and 9\% solar capacity additions were dedicated to general RPS and solar/distributed generation carve-out obligations respectively (Barbose, 2021). 


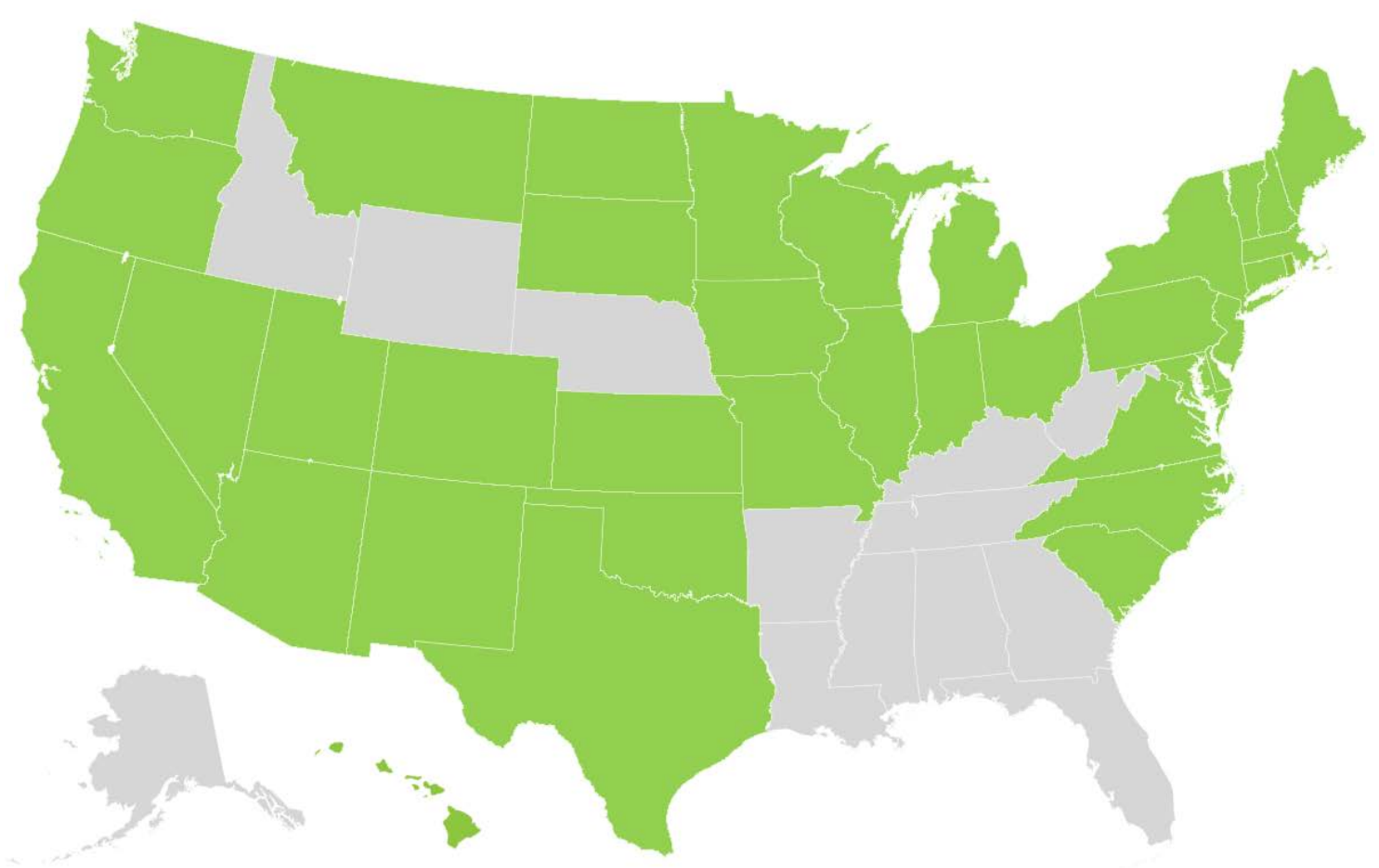

Figure 1. U.S. states that enable RPS or equivalent mandates

\section{Net Energy Metering}

Net energy metering (NEM) allows customers with DERs to serve their energy onsite and receive energy credits for any surplus energy fed back to the grid. By 2020, 40 states and Washington, D.C had mandatory NEM rules (DSIRE, 2020a). Traditionally, NEM programs allow customers to receive compensation at the retail rate. But with the decreasing DER costs, some states are redesigning their NEMs to develop new approaches for billing and crediting. For example, states such as Arizona, California, Hawaii, Massachusetts, and Vermont have adopted some new NEM tariffs (DSIRE, 2020a). In addition to general NEM dedicated to customersowned DER, other programs such as virtual net energy metering, NEM aggregation, community solar, and multifamily affordable solar housing allow customers with limited access to DERs to earn NEM benefits.

\section{Renewable Energy Auctions}

A renewable energy auction is a competitive procurement mechanism for renewables capacity $(\mathrm{kW})$ or energy $(\mathrm{kWh})$ whereby the buyer (e.g., a utility or large consumer) issues a call for proposals for developers to install a system of specified size and other characteristics. Bidders compete exclusively on price, with no additional features added and no negotiation. Auctions are flexible (e.g., allow for assigning responsibility for feasibility studies to either the buyer or bidder) and may be implemented in various ways (e.g., static or dynamic bids) to meet local market/policy conditions and goals. And winning bids enter long-term power purchase agreements with buyers (IRENA, 2015; USAID, 2019). 


\section{Renewable Energy Subsidies}

Renewable energy subsidies play an important role in DER development by reducing expenditures, especially upfront costs. This element includes renewable investment and the federal investment tax credit, grants, rebate programs, loans, financing and other incentive schemes. Subsides can apply at the federal and state levels, and they can be provided by utilities as well. For example, the federal solar investment tax credit currently provides a $26 \%$ tax credit for both residential and commercial properties constructions (SEIA, 2021a). At the state level, California, for example, provides a rebate program for solar systems dedicated to low-income residential customers (DSIRE, 2021).

\section{DER Ratemaking}

Traditionally, the ratemaking process for a utility was to collect a reasonable revenue to cover capital and operating expenses. Traditionally, an authorized utility collected revenue to cover capital and operating expenses. DERs reduce a utility's energy procurement, which saves expenses. However, the increasing DER participants such as third-party and demand-sited systems would affect the ratemaking process as they are not in the utility's capital expenses (Lowder and $\mathrm{Xu}, 2020$ ). The challenge for ratemaking is to ensure DER and non-DER customers still pay their fair share of capital costs.

\subsection{States' and Utilities: Efforts on DER}

In the grid system, vertical unbundling refers to the separation of generation, transmission, distribution, and retail services. In the 1990s, FERC's Orders 888 and 889 on creating independent system operator and regional transmission operators (RTOs) unbundled generation from transmission. In some parts of the country, retail choices have allowed customer to purchase electricity from competitive retail suppliers, thereby unbundling the retail services in some states. Greater DER deployment would result in increasing fragments of power sector and would require more-flexible business models (Fuentes-Bracamontes, 2016). Also, reconstructed wholesale market efforts since the 1990s form a competitive power market frame that allows the market to determine which power suppliers provide electricity generation based on the price offered.

In addition to fundamental policy and market schemes, states and utilities have developed detailed DER and grid modernization approaches to accelerate DER development. States such as California, New York, and Massachusetts are leading the DER adoption in the United States. These states, as illustrated in Table 3, have developed long-term distribution plans, evaluated the value of DERs, created DER procurement strategies, and made other regulatory mandate and taken alternative market approaches. In addition, FERC Order 2222, which was issued in 2020, directs RTOs to establish rules by which DERs can participate in wholesale markets through aggregation (FERC, 2020a). 
Table 3. Distribution System Planning and Grid Modernization Activitya

\begin{tabular}{|c|c|c|c|c|c|c|c|c|c|c|c|c|c|c|c|c|c|c|c|c|c|c|c|c|c|}
\hline \multirow[b]{2}{*}{$\begin{array}{l}\text { Distribution } \\
\text { System } \\
\text { Planning and } \\
\text { Grid } \\
\text { Modernizatio } \\
\text { n Activity }\end{array}$} & \multicolumn{25}{|c|}{$\begin{array}{l}\text { Advanced } \\
\text { Practices }\end{array}$} \\
\hline & 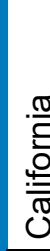 & := & 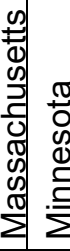 & 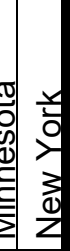 & 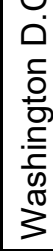 & \begin{tabular}{|l}
$\frac{\pi}{0}$ \\
$\frac{0}{4}$ \\
$\frac{0}{4}$
\end{tabular} & $\begin{array}{l}. \frac{\infty}{0} \\
\stackrel{\varrho}{\equiv} \\
\end{array}$ & $\begin{array}{l}\underset{\sigma}{c} \\
\frac{\pi}{0} \\
\underline{\underline{D}}\end{array}$ & $\begin{array}{l}\frac{0}{2} \\
\frac{\pi}{2} \\
2 \\
\frac{\pi}{2}\end{array}$ & 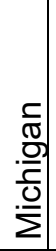 & $\frac{.}{\mathrm{O}}$ & 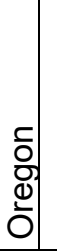 & \begin{tabular}{l|}
$\frac{0}{2}$ \\
$\frac{0}{0}$ \\
2 \\
की \\
$\frac{0}{0}$ \\
0 \\
0
\end{tabular} & $\begin{array}{l}\frac{0}{\frac{0}{0}} \\
\frac{0}{0} \\
\frac{0}{8} \\
\frac{D}{\alpha}\end{array}$ & 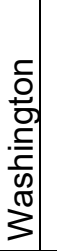 & 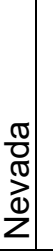 & 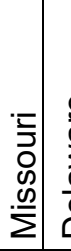 & 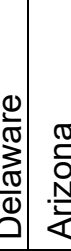 & $\begin{array}{l}0 \\
0 \\
\frac{\pi}{0} \\
0 \\
0 \\
0\end{array}$ & 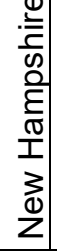 & @) & 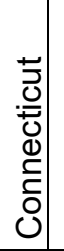 & . & 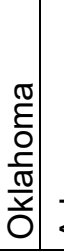 & 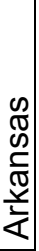 \\
\hline $\begin{array}{l}\text { Statutory } \\
\text { requirement for } \\
\text { long-term } \\
\text { distribution } \\
\text { plans or grid } \\
\text { modernization } \\
\text { plans }\end{array}$ & $\checkmark$ & & $\checkmark$ & & & & & & & & & & & & & & & & & & & & & & \\
\hline $\begin{array}{l}\text { Commission } \\
\text { requirement for } \\
\text { long-term } \\
\text { distribution } \\
\text { plans or grid } \\
\text { modernization } \\
\text { plans }\end{array}$ & & $\checkmark v$ & & $\checkmark$ & & & & & $\checkmark$ & $\checkmark$ & & & & & & $\checkmark$ & $\checkmark$ & $1 \checkmark$ & & & & & & & \\
\hline $\begin{array}{l}\text { No planning } \\
\text { requirements } \\
\text { yet but } \\
\text { proceeding, } \\
\text { underway, or } \\
\text { planned }\end{array}$ & & & & & $\checkmark$ & & $\checkmark$ & & & & $\checkmark$ & $\checkmark$ & & $\checkmark$ & $\checkmark$ & & $\checkmark$ & & $\checkmark$ & $\checkmark$ & & & & & \\
\hline $\begin{array}{l}\text { Efforts or early- } \\
\text { stage actions tc } \\
\text { support DERs } \\
\text { or grid } \\
\text { modernization }\end{array}$ & & & & & & $\checkmark$ & & $\checkmark$ & & & & & & & & & & & & & $\checkmark$ & & & $\checkmark \vee$ & $\checkmark$ \\
\hline $\begin{array}{l}\text { Voluntary filing } \\
\text { of grid } \\
\text { modernization } \\
\text { plans }\end{array}$ & & & & & & & $\checkmark$ & $\checkmark$ & & & $\checkmark$ & & $\checkmark$ & & & & & & & & & & & & \\
\hline $\begin{array}{l}\text { No-wires } \\
\text { alternatives } \\
\text { analysis }\end{array}$ & $\checkmark$ & & & $\checkmark$ & & & & & & & & & & $\checkmark$ & & & & & & & $\checkmark$ & & & & \\
\hline $\begin{array}{l}\text { Hosting } \\
\text { capacity } \\
\text { analysis } \\
\text { requirements }\end{array}$ & $\checkmark$ & & $\checkmark$ & & & & & & & & & & & & & & & & & & & & & & \\
\hline $\begin{array}{l}\text { Locational net } \\
\text { benefits }\end{array}$ & & & & $V$ & & & & & & & & & & & & 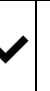 & & & & & & & & & \\
\hline
\end{tabular}




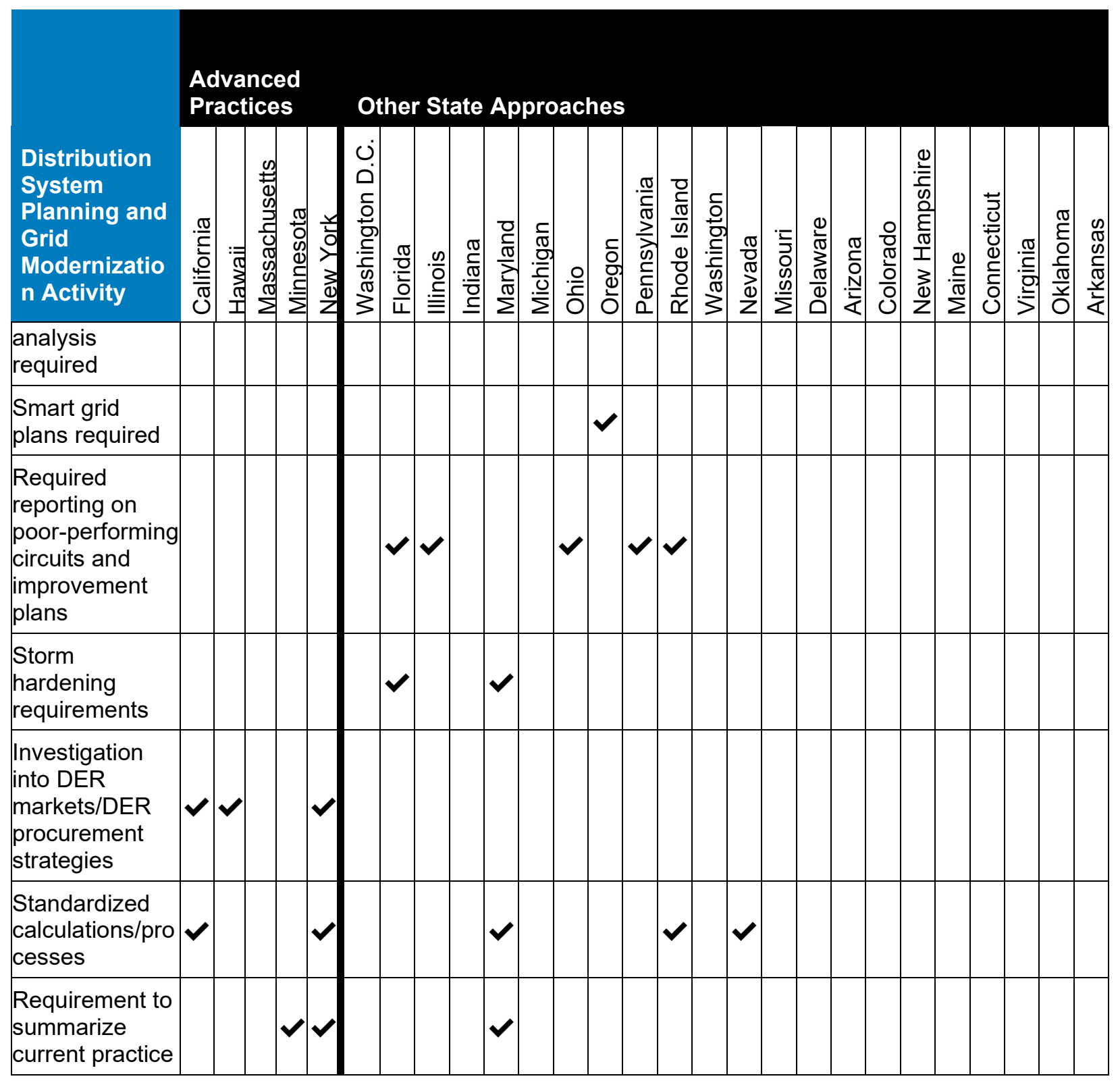

a Based on Homer et al. 2017 (Table S-1)

Sources: (Homer et al., 2017); (Cooke, Schwartz and Homer, 2018); (GridWise Alliance, 2018); (Proudlove, Lips and Sarkisian, 2020); (Schwartz, 2017); (Girouard, 2019) 


\section{DER Market Participants}

Entities that play defining roles in the design, establishment, operation, and provision of services under a DER market include government departments and agencies, utilities and system operators, independent power producers (IPPs), energy service providers (ESPs), and DER aggregators. Their roles relative to DER markets are briefly introduced in this section.

\subsection{Government Departments and Agencies}

Government departments and agencies serve as the source of energy policy and the ultimate regulator of energy market participants. National governments often transfer decision making authority to other entities, such as provincial or city-level authorities, or to governing bodies established specifically to perform utility oversight, such as public utility commissions. With respect to DERs, governments may set regulations for private sector involvement in the energy market, establish goals or requirements for amounts of generation capacity sourced from renewable energy, specify the codes and standards to be used for energy asset operations, and set rules for determining tariffs.

The viability of market participants and DER business models highlighted in this report depend on government policies and regulations that eliminate unreasonable obstacles to third party DERs and allow for price signals that appropriately reward DERs for the value provided to the system to reach customers. ${ }^{1}$ The business models described in Section 4 will generally be unviable if a government fails to remove obstacles, and all the models will most effectively incentivize investment if the market can provide proper price signals. Necessary policies include allowance for both private sector ownership of electricity generation capacity and direct electricity sales between private parties. Other government-based mechanisms that can incentivize investment more effectively but do not necessarily include attractive feed-in-tariffs, net energy metering (NEM) or net energy billing, time-of-use pricing, priority dispatch to DERs.

\subsection{Utilities and System Operators}

Utilities provide electricity to consumers, while system operators ensure the proper functioning of the electric grid. A range of existing utility operating regimes allow for differing levels of aggregation and private sector involvement in generation, grid system operations, transmission, and distribution services. Vertically integrated monopolistic utilities may perform all these power system activities, including system operations, and they may allow for only limited private sector involvement in a given geography. As a result, in vertically integrated regimes, expanding DER utilization within the power system requires extensive investment in generation and grid management technologies and capabilities by the utility. Conversely, disaggregated power systems - with independent system operators and extensive private sector ownership of grid assets - shift many of the investment costs and risks from the utility to private investors.

\footnotetext{
${ }^{1}$ Several approaches exist for determining appropriate compensation for DER services, including the Value of Distributed Energy Resources compensation framework developed by the New York Department of Public Service.
} 


\subsection{Independent Power Producers (IPPs)}

IPPs are private sector companies authorized to generate and sell electricity directly to a utility or private customers through a power purchase agreement. IPPs are used extensively in competitive markets and are also frequently used in regulated ones. IPPs may generate electricity at varying scales (e.g., rooftop PV or utility scale) and from the full range of sources (e.g., wind and geothermal), and they may operate either on- or off-grid projects depending on applicable regulations.

IPP-owned DERs can provide flexible generation capacity that can be coordinated with system operator needs to support grid stability and optimize grid-wide generation costs. Potential costs that may be incurred include policy development, regulatory oversight, and minor equipment installation for managing power flow; however, these costs may be defrayed through connection and wheeling fees. The use of IPPs leverages private sector financial resources and technical capacity to increase renewable energy generation capacity and promote grid stability without the need for upfront government or utility investment.

\subsection{Energy Service Providers (ESPs)}

ESPs, also referred to as energy service companies, are private sector entities that can offer a range of services such as energy efficiency upgrades, battery storage for time-of-use optimization, and operation and maintenance aimed at reducing customers' energy costs.

Customers retain ownership of DERs used in these services, and they maintain the primary relationship with utilities, while the ESP provides DER management services. Typical ESP service models are designed around contracts that pay the ESP a fee for a guaranteed financial savings via operational improvements for the customer.

\subsection{DER Aggregators}

FERC introduced the concept of DER aggregators to increase the value and market participation of DERs in its Order 2222 (FERC, 2020b). An aggregator is a single point of contact representing many dispersed DER owners in bulk electricity markets operated by an RTO. The RTO pays the aggregator based on the aggregator's responses in the wholesale market, and the aggregator pays its subscribing DER owners according to their contributions to the responses for which the aggregator is paid by the RTO. (As of this writing, most RTOs were still developing their rules for DER aggregator participation.) A critical aspect of FERC Order 2222 is that it provides for DERs to be aggregated by a single entity to meet minimum size and performance requirements that had previously hindered DER involvement in market activities. 


\section{Business Models}

As discussed in previous sections, policy and market elements serve as market preparation to enable the DER developments. Depending on the business model in place, DER applications involve some or all participants discussed in Section 3. The business models described in this report fit most readily into the deregulated markets aimed at economically meeting consumer demand while supporting reliable and efficient electricity system operations through broad private sector participation. These business models may also be used in vertically integrated regimes if they are implemented through purposeful policy design. In this section, we review the business models for adopting DERs, including both present practices and early-stage options.

Table 4 highlights the business models covered in this section, all of which may be used in either regulated or deregulated electricity markets. They are categorized as either requiring utility involvement Section 4.2) or not (Sections 4.1). For each business model, another table summarizes the model's required and supportive features, and its advantages and disadvantages.

Table 4. DER Business Models

\begin{tabular}{|l|l|}
\hline Models Without Utility Involvement & Models With Utility Involvement \\
\hline - Islanded microgrids & - Ancillary services \\
- Customer-side power management & - Community solar \\
& - DER aggregation \\
& - Peer-to-Peer \\
\hline
\end{tabular}

\subsection{Business Models With No Utility Involvement}

Models without utility involvement rely primarily on private sector investments and financing, and they generally do not require significant government or utility financial expenditures. Notably, such models may be enhanced with optional government-funded incentives. They typically rely on policy or regulatory mechanisms that authorize relevant private sector activities.

\section{Model 1: Islanded Microgrids}

Private sector development of microgrids to serve consumer loads in areas with no or limited access to electricity or that require unique power supply (S\&P Global, 2020)

In this model, private sector developers obtain the right to install small-scale generation and distribution capacity, and they establish billing and administrative capabilities for unserved customers. Under this model, "detachable" systems allow customer-owned microgrids to be operated independently from utility grids during outages and connected during normal operations.(S\&P Global, 2020). In certain policy settings, this may mean the utility offers a concession to private sector developers for a given period, potentially for a fee or as part of a public-private-partnership. 
Table 5. Islanded Microgrids Model: Required and Supportive Features, Advantages and Disadvantages

\begin{tabular}{|c|c|}
\hline Required Policies/Regulations & Supportive Policies/Regulations \\
\hline $\begin{array}{l}\text { allow private sector generation and sale of } \\
\text { electricity to end users }\end{array}$ & $\begin{array}{l}\text { Include financial incentives that subsidize costs } \\
\text { and/or reduce risks for developers, particularly in } \\
\text { underdeveloped geographies }\end{array}$ \\
\hline Advantages & Disadvantages \\
\hline $\begin{array}{l}\text { - Low risk and low-cost (for the utility) provision } \\
\text { of electricity services to underserved markets } \\
\text { - Improved electrification rates at reduced costs } \\
\text { compared to new transmission lines to the } \\
\text { utility or government } \\
\text { - As the utility grid expands in nearby } \\
\text { geographies, the microgrids may be } \\
\text { connected to larger grid systems. } \\
\text { - Information exchange opportunities with the } \\
\text { private sector under public-private-partnership } \\
\text { schemes }\end{array}$ & $\begin{array}{l}\text { - Potential loss of revenue for the utility in areas } \\
\text { where utility grid expansion is eventually } \\
\text { expected } \\
\text { - Risk associated with relinquishing } \\
\text { development concession rights } \\
\text { - Utilities may face under-recovery of fixed } \\
\text { costs when interconnecting the microgrid } \\
\text { under certain conditions. }\end{array}$ \\
\hline
\end{tabular}

\section{Model 2: Customer-Side Power Management}

Behind-the-meter equipment installation or services provided by the private sector to manage power for private electricity consumers to reduce consumers' costs and/or improve reliability Services may include load management, energy efficiency, captive power generation, backup power, and storage. Under this model, projects can be implemented at no cost to the utility, but resulting changes in consumer demand for grid-based electricity may reduce utility revenue. In addition, electricity consumers, including commercial, industrial, and residential, may fund selfimplement solutions or hire ESPs to implement solutions or provide, for example "energy as a service" (Cleary and Palmer, 2019).

Targeted private sector investments include those for reducing power demand through efficiency improvements in operations or technology upgrades; shifting time of use to reduce bills (Utility Dive, 2019; Seattle City Light, 2021); installing energy management systems to optimize power use; generating electricity for on-site use; and installing generators to provide backup power. 
Table 6. Customer-Side Power Management Model: Required and Supportive Features, Advantages and Disadvantages

\begin{tabular}{|c|c|}
\hline Required Policies/Regulations & Supportive Policies/Regulations \\
\hline $\begin{array}{l}\text { - Customer-side power generation allowed } \\
\text { - Customer-side business transactions for } \\
\text { energy services allowed } \\
\text { - For "detachable" mini-grids, grid connection } \\
\text { policies and procedures must be developed } \\
\text { and implemented }\end{array}$ & $\begin{array}{l}\text { - Time of use rates that that leverage price } \\
\text { sensitive demand to incentivize peak shaving } \\
\text { - Energy efficiency incentives } \\
\text { - Incentives to encourage investment in } \\
\text { customer-side technologies can help spur } \\
\text { investment. }\end{array}$ \\
\hline Advantages & Disadvantages \\
\hline $\begin{array}{l}\text { - Load reduction can reduce investment } \\
\text { required for capacity expansion. } \\
\text { - Time of use rates may be used to incentivize } \\
\text { consumer investments resulting in peak } \\
\text { shaving. }\end{array}$ & $\begin{array}{l}\text { - Potential loss of revenue for the utility as a } \\
\text { result of decreased electricity sales, resulting } \\
\text { in shifting costs to other customers } \\
\text { - May require the utility to recalibrate load } \\
\text { forecasting techniques } \\
\text { - If not managed properly, private-sector } \\
\text { switching to variable renewable energy may } \\
\text { introduce additional variability to load. }\end{array}$ \\
\hline
\end{tabular}

\subsection{Business Models Depending on Policy and Utility Applications}

Models with utility involvement entail direct interaction between the private sector and the utility, and they require supportive government policy and regulatory support. Utilities must be equipped with and capable of both incorporating additional and often variable electricity and taking advantage of grid services provided by DERs. In competitive markets, price signals based on the supply and demand of electricity and grid services drive many key decisions in DER utilization.

\section{Model 1: Ancillary Services}

Active management by system operators of privately-owned DERs to control grid characteristics that influence electricity reliability and quality

This model includes load management and regulation, reactive power support, reserve management, frequency control, and fault ride through capabilities (Watanabe et al., 2011; Kiliccote, M.A. and Ghatikar, 2015).

- Private investors install or hire project developers to install ancillary service-providing assets.

- Contracts between grid operators and asset owners can be established via several avenues, including open bids, auctions and organized markets; alternatively, ancillary services can be implemented via interconnection requirements or other administrative mechanisms (Cochran, 2015).

- Ancillary service mechanisms are widely used in competitive markets; they could be used in regulated markets but are largely untested.

- There is a moderate cost to the utility that is related to installing and operating infrastructure and data management functions to utilize ancillary services, and administrative capabilities to establish policies and manage contracts. 


\section{Table 7. Ancillary Services Model: Required and Supportive Features,}

Advantages and Disadvantages

\section{Required Policies/Regulations/Technologies Supportive Policies/Regulations}

- Private-sector provision of ancillary services

- Ancillary service pricing and procurement

- Grid access

- Up-to date grid codes that accommodate and dictate requirements for grid-connected DERs with advanced control capabilities

- Utility-side ability to forecast, define and control ancillary services, such as the Flexible AC Transmission System

- Supplier-side ability to provide continuous system characteristic measurements (Koch, 2015)

\section{Advantages}

- Can increase the value of grid-connected renewable energy

- Can be used to reduce grid congestion and investment costs in grid reserve and other grid management functions
- Organized ancillary service markets and trading platforms

\section{Model 2: Community Solar}

Joint investment in PV generation facilities by individual small-scale consumers through user subscriptions or shared ownership models

In this model, customers subscribe to a community solar facility and receive an energy benefit based on the share of electricity generated by the facility; facility operators coordinate with utilities to net the generation against customers' bills. Community solar ownership models include utility-lead, developer-owned, and third-party ownership, and NEM serves as the fundamental scheme of this business model. The costs to the utility may include developing and implementing policies and billing mechanisms. 
Table 8. Community Solar Model: Required and Supportive Features, Advantages and Disadvantages

\begin{tabular}{|c|c|}
\hline Required Policies/Regulations/Technologies & Supportive Policies/Regulations \\
\hline $\begin{array}{l}\text { - Virtual net metering capabilities and } \\
\text { compensation } \\
\text { - Allowance for private-sector generation } \\
\text { and sale of electricity } \\
\text { - Interconnection } \\
\text { - Bidirectional meters } \\
\text { - Supply and demand forecasting tools } \\
\text { and response capabilities }\end{array}$ & $\begin{array}{l}\text { - Priority dispatch } \\
\text { - Meter aggregation (Linvill and Brutkoski, } \\
\text { 2017) }\end{array}$ \\
\hline Advantages & Disadvantages \\
\hline $\begin{array}{l}\text { - Can reduce utility investment costs for large- } \\
\text { scale generation capacity } \\
\text { - Supports private sector investment with no } \\
\text { upfront cost to consumers } \\
\text { - Provides opportunities for customers with } \\
\text { limited rooftop and solar installation conditions } \\
\text { to access solar resources } \\
\text { - Project investors receive the benefits from } \\
\text { economies of scale. }\end{array}$ & $\begin{array}{l}\text { - Utilities may lose customers and revenue. } \\
\text { - Project developer risks exist that are related } \\
\text { to subscriber acquisition; without financing } \\
\text { and incentives, the net present value may be } \\
\text { insufficient to encourage project development. } \\
\text { Other considerations: } \\
\text { - Utility may need to establish project number } \\
\text { and size limitations to avoid oversupply. } \\
\text { - Utility may need to create a new tariff specific } \\
\text { to the value provided by community solar } \\
\text { plants (including the process for crediting the } \\
\text { value to subscribing customers). }\end{array}$ \\
\hline
\end{tabular}

\section{Model 3: DER Aggregation}

Aggregation of colocated or geographically dispersed DERs, including battery storage and electric vehicles (EVS), to provide dispatchable power and ancillary services; also known as virtual power plants (VPPS)

The value of establishing VPPs was enhanced in the U.S. by FERC Order 2222, as noted in Section 2.3. VPPs are integrated into the grid by aggregating large numbers of distributed behind-the-meter generators, controllable loads and energy storage systems that can be managed on demand using aggregation software to monitor and control constituent DERs.

DER capacity may be owned by private entities, or leased to private owners by the utility (Willson, 2020). Private owners can sell capacity or grid services to the utility during periods of high demand; alternatively, the utility can offer credit to private owners for access to the DER capacity. In addition, VPPs are fairly new mechanisms in deregulated markets; they could apply in regulated markets but are untested.

This model can be implemented at low or no cost to utilities, and the potential costs relate to policy development, program administration, and minor equipment installation. 
Table 9. DER Aggregation Model: Required and Supportive Features, Advantages and Disadvantages

\begin{tabular}{|c|c|}
\hline Required Policies/Regulations/Technologies & Supportive Policies/Regulations \\
\hline $\begin{array}{l}\text { - Interconnection } \\
\text { - Private sector generation } \\
\text { - Systems must have a sufficient network of } \\
\text { DERs. } \\
\text { - Multidirectional data exchange between the } \\
\text { DERs and grid operator } \\
\text { - Centralized system to synchronize and } \\
\text { process complex real-time supply and } \\
\text { demand data } \\
\text { - Centralized control system to manage DERs }\end{array}$ & - Trading platform to facilitate transactions \\
\hline Advantages & Disadvantages \\
\hline $\begin{array}{l}\text { - VPPs can provide an additional way to } \\
\text { balance demand and supply. VPPs aggregate } \\
\text { flexible capacity to address peaks in electricity } \\
\text { demand without investment in peaking } \\
\text { capacity. Battery storage, specifically, can } \\
\text { provide capacity to quickly manage short-term } \\
\text { supply deficits. } \\
\text { - Can boost distribution system reliability with } \\
\text { managed grid-stabilizing resources } \\
\text { - Can lead to market scaling and greater } \\
\text { economic value }\end{array}$ & $\begin{array}{l}\text { - To be most efficient, private system owners } \\
\text { must allow for some utility (or other } \\
\text { aggregator) control of DERs. } \\
\text { - Implementing billing and payment } \\
\text { mechanisms can be complex. } \\
\text { Other considerations: } \\
\text { - Requires utility to create a benchmarking } \\
\text { methodology to monitor DER supplier } \\
\text { response; payments from the utility are } \\
\text { reduced if the supplier fails to respond as } \\
\text { agreed } \\
\text { - value to subscribing customers) }\end{array}$ \\
\hline
\end{tabular}

\section{Model 4: Peer-to-Peer Trading}

Direct sale via trading platforms of DER services between private on-grid consumer, with value derived from dynamic matching of supply and demand that optimizes economic efficiency (Morstyn et al., 2018)

Private sector participants hire developers or self-install grid-connected and remotely dispatchable DERs; DERs are connected to a network of prosumers who buy and sell DER services to meet mutual supply and demand needs. And electronic platforms facilitate financial transactions between peers and DER management on subhourly time intervals based on transparent supply and demand data.

Peer-to-peer mechanisms are being piloted in deregulated markets; they could apply in regulated markets but are untested. Costs to utility may include policy administration and peer use of electricity distribution network, ideally over short distances. 
Table 10. Peer-to-Peer Trading Model: Required and Supportive Features, Advantages and Disadvantages

\section{Required Policies/Regulations/Technologies}

- Interconnection

- Power wheeling

- Private-sector generation and sale of electricity and other DER services

- Private-sector use of electronic trading and remote DER management platforms

- Behind-the-meter data processing and power management

- Grid operator response to the impact peer trading has on supply and demand forecasts for grid operations

\section{Advantages}

- Can reduce utility investment costs in largescale generation capacity

- Can provide prosumers with extensive sourcing options, and energy matching; in competitive markets, can provide a hedge against price variability

- Can reduce grid congestion when coupled with time-of-use pricing

\section{Supportive Policies/Regulations}

- Time-of-use pricing to incentivize power management strategies that both prosumers and the utility can optimize

- Allow for blockchain transactions

\section{Disadvantages}

- Requires transparency and access to peers' supply and demand data, which may introduce privacy concerns

- Could result in lost sales revenues for the utility

- Infrastructure costs to support power management and transactions can be significant for small scale/individual prosumers 


\section{Conclusion}

DERs provide values to all stakeholders, and deployment of DERs is increasing; however, they are also challenging traditional generation, transmission, and distribution grid system operations. Federal and state-level renewable mandate, power market design, incentives, and rate making play important roles for moving the barriers of developing a DER market.

DER implementation brings more stakeholders to the market, and DERs thus require more complex coordination among generators, utilities, retailor sellers, customers, and other parties. Many business models require utility participations to ensure fully integrated DER values. On the other hand, approaches such as customer-side power management and island-microgrid systems requires less or no utility involvements. Some DER technologies like peer-to-peer DER trading is still in early-stage development and need more efforts to remove development barriers. 


\section{References}

Barbose, G. (2021) U.S. Renewables Portfolio Standards 2021 Status Update : Early Release. Available at: https://eta-publications.lbl.gov/sites/default/files/rps_status_update2021_early_release.pdf.

California Legislative Information (2018) SB-100 California Renewables Portfolio Standard Program: emissions of greenhouse gases. Available at:

https://leginfo.legislature.ca.gov/faces/billTextClient.xhtml?bill_id=201720180SB100.

Cleary, K. and Palmer, K. (2019) 'Energy-as-a-Service : A Business Model for Expanding Deployment of Low-Carbon Technologies’, (December).

Cochran, J. L. J. (2015) 'Methods for Procuring Power System Flexibility', Greening the Grid, p. 2.

Cooke, A. L., Schwartz, L. C. and Homer, J. S. (2018) 'Distribution System Planning-State Examples by Topic', (May). Available at: https://epe.pnnl.gov/pdfs/DSP_State_ExamplesPNNL-27366.pdf.

DSIRE (2020a) Net Metering. Available at: https://s3.amazonaws.com/ncsolarcen-prod/wpcontent/uploads/2020/06/DSIRE_Net_Metering_June2020.pdf.

DSIRE (2020b) Renewable \& Clean Energy Standards. Available at: https://s3.amazonaws.com/ncsolarcen-prod/wp-content/uploads/2020/09/RPS-CESSept2020.pdf.

DSIRE (2021) California Solar Initiative - Single-Family Affordable Solar Housing (SASH) Program. Available at: https://programs.dsireusa.org/system/program/detail/3673.

FERC (2018) 'Distributed Energy Resources Technical Considerations for the Bulk Power System', Energy for Sustainability, (February), pp. 313-339. doi: 10.5822/978-1-61091-8213_10.

FERC (2020a) FERC Opens Wholesale Markets to Distributed Resources: Landmark Action Breaks Down Barriers to Emerging Technologies, Boosts Competition. Available at: https://www.ferc.gov/news-events/news/ferc-opens-wholesale-markets-distributed-resourceslandmark-action-breaks-down.

FERC (2020b) FERC Order No. 2222: Fact Sheet. Available at: https://www.ferc.gov/media/ferc-order-no-2222-fact-sheet.

Frick, N. M. et al. (2021) 'Lawrence Berkeley National Laboratory Locational Value of Distributed Energy Resources Principal Authors’, (February).

Fuentes-Bracamontes, R. (2016) 'Is unbundling electricity services the way forward for the power sector?', Electricity Journal. Elsevier Inc., 29(9), pp. 16-20. doi:

10.1016/j.tej.2016.10.006. 
Girouard, C. (2019) Top 10 Utility Regulation Trends of 2019 - So Far, GTM. Available at: https://www.greentechmedia.com/articles/read/top-10-utility-regulation-trends-of-2019-so-far.

GridWise Alliance (2018) 2018 Grid Modernization Index (GMI-2018). Available at: https:/gridwise.org/grid-modernization-index-2018/.

Homer, J. et al. (2017) 'State Engagement in Electric Distribution Planning', (December), p. December. Available at:

https://emp.lbl.gov/sites/default/files/state_engagement_in_dsp_final_rev2.pdf\%0Ahttps://emp.1 bl.gov/publications/state-engagement-electric.

IRENA (2015) 'Renewable Energy Auctions: A Guide to Degisn'. Available at: https://www.irena.org//media/Files/IRENA/Agency/Publication/2015/IRENA_RE_Auctions_Guide_2015_1_summary. pdf?la=en\&hash=8BC6E969385A962230829946F07827D68A13C99C.

Kiliccote, S., M.A., P. and Ghatikar, R. (2015) 'Improved energy demand management in buildings for smart grids: The US experience'. doi: https://doi.org/10.1016/B978-1-78242-0101.00015-X.

Koch, S. (2015) Assessment of Revenue Potentials of Ancillary Service Provision by Flexible Unit Portfolios, Energy Storage for Smart Grids: Planning and Operation for Renewable and Variable Energy Resources (VERs). Elsevier Inc. doi: 10.1016/B978-0-12-410491-4.00002-6.

Linvill, C. and Brutkoski, D. (2017) 'Designing Distributed Generation in Mexico', (June 2015). Available at: https://www.nrel.gov/docs/fy17osti/66026.pdf.

Lowder, T. and Xu, K. (2020) 'The Evolving U.S. Distribution System : Technologies, Architectures, and Regulations for Realizing a Transactive Energy Marketplace', (May).

De Martini, P. and Kristov, L. (2015) 'Distribution Systems in a high distributed energy resources future Planning, Market Design, Operation and Oversight’, (2).

Morstyn, T. et al. (2018) 'Using peer-to-peer energy-trading platforms to incentivize prosumers to form federated power plants', Nature Energy. Springer US, 3(2), pp. 94-101. doi: $10.1038 / \mathrm{s} 41560-017-0075-\mathrm{y}$.

NREL (2021) Community Solar. Available at: https://www.nrel.gov/state-localtribal/community-solar.html.

Proudlove, A., Lips, B. and Sarkisian, D. (2020) 50 States of Grid Modernization. Available at: https://nccleantech.ncsu.edu/wp-content/uploads/2020/04/Q12020_gridmod_exec_final.pdf.

S\&P Global (2020) In summer of darkness, distributed energy offers brighter future for US West. Available at: https://www.spglobal.com/marketintelligence/en/news-insights/latest-newsheadlines/in-summer-of-darkness-distributed-energy-offers-brighter-future-for-us-west60369551 (Accessed: 20 January 2009). 
Schwartz, L. (2017) PUC Distribution Planning Practices. Available at: https:/etapublications.lbl.gov/sites/default/files/12__schwartz_puc_distribution_planning_practices.pdf.

Seattle City Light (2021) Energy Efficiency as a Service. Available at: https://powerlines.seattle.gov/eeas/.

SEIA (2021a) Solar Investment Tax Credit (ITC). Available at:

https://www.seia.org/initiatives/solar-investment-tax-credit-itc (Accessed: 20 January 2009).

SEIA (2021b) U.S. Solar Market Insight. Available at: https://www.seia.org/us-solar-marketinsight.

Tierney, S. F. (2016) 'The Value of "DER" to "D": The Role of Distributed Energy Resources in Supporting Local Electric Distribution System Reliability', 2016, p. 61. Available at:

http://www.analysisgroup.com/uploadedfiles/content/news_and_events/news/value_of_der_to _d.pdf.

USAID (2019) 'Designing renewable energy auctions: a policymaker's guide. Scaling up renewable energy project', (July). Available at:

https://www.usaid.gov/sites/default/files/documents/1865/USAID-SURE_Designing-RenewableEnergy-Auctions-Policymakers-Guide.pdf.

Utility Dive (2019) An emerging push for time-of-use rates sparks new debates about customer and grid impacts. Available at: https://www.utilitydive.com/news/an-emerging-push-for-time-ofuse-rates-sparks-new-debates-about-customeran/545009/?utm_source=Sailthru\&utm_medium=email\&utm_campaign=Issue: 2020-12-30 Top Utility Trends \%5Bissue:31552\%5D\&utm_term=Utility Daily \%2B Weeklies \%2B Weekender.

Watanabe, E. H. et al. (2011) Flexible AC transmission systems. 4th edn, Power Electronics Handbook. 4th edn. Elsevier Inc. doi: 10.1016/B978-0-12-382036-5.00032-X.

Willson, M. (2020) How 'virtual power plants' are changing renewables, E\&E News. Available at:

https://login.politicopro.com/?redirect=https\%3A\%2F\%2Fsubscriber.politicopro.com\%2Farticle $\% 2 \mathrm{Feenews} \% 2 \mathrm{~F} 1063721307 \&$ s=eenews.

Wood Mackenzie (2021) U.S. Solar Market Insight Full report Q2 2021. Available at: https://www.woodmac.com/reports/power-markets-u-s-solar-market-insight-q2-2021-501025. 